\title{
Chemical Budbreak Induction Methods to Increase Blackberry Yields under Inadequate Chilling Conditions ${ }^{1}$
}

\author{
Shinsuke Agehara and Syuan-You Lin²
}

Blackberry (Rubus L. subgenus Rubus Watson) is a deciduous berry crop grown primarily in temperate regions. California and Oregon are the leading states in fresh-market and processing blackberry production, respectively. Blackberry production has recently expanded to the Southeast, such as Georgia, Arkansas, and North Carolina, where the production acreage increased by $52 \%$ (2461 vs. 3735 acres) from 2007 to 2017 (US Department of Agriculture 2017). In Florida, however, inadequate winter chill limits blackberry production by causing poor and erratic budbreak. To compensate for lack of winter chill, we developed chemical budbreak induction methods based on field trial data collected over three growing seasons (Lin and Agehara 2020b; Lin and Agehara 2021a). This article is intended to provide Florida growers with guidelines on how to improve budbreak of current major blackberry cultivars, with the aim of supporting the development of subtropical blackberry production. The information in this article is also available at the UF IFAS Horticultural Crop Physiology Lab YouTube channel (https://youtube.com/playlist?list=PL 4qrjj3jZ6i7li14VC_gu4qPl2V1gs2tO).

\section{Plant Phenology}

Blackberry cultivars are classified into two types based on fruiting characteristics: floricane- and primocane-fruiting cultivars. The first-year canes that grow until plants enter dormancy are called primocanes, and primocanes become floricanes after overwintering. Traditional blackberry cultivars belong to the floricane-fruiting type, which flower and fruit only on floricanes. Some new blackberry cultivars belong to the primocane-fruiting type, which produces berries on both primocanes and floricanes. The reproductive phenology of both floricane- and primocane-fruiting cultivars grown in central Florida is described below.

\section{Floricane-Fruiting Type}

Floricane-fruiting cultivars develop flower buds on primocanes in late fall. Defoliation of floricanes occurs between late December and mid-February, depending on the timing and amount of winter chill. Budbreak occurs from late February to mid-March, and plants produce berries from early May to late June (Lin and Agehara 2020a).

\section{Primocane-Fruiting Type}

Primocane-fruiting cultivars produce berries on primocanes from mid-October to late February and again on floricanes from late April to mid-June in the following year. In central Florida, however, fruit production on primocanes is low over a prolonged period. Consequently, only the berries produced on floricanes are harvested in commercial production.

1. This publication is HS1419, one of a series of the Horticultural Sciences Department, UF/IFAS Extension. Original publication date August 2021. Visit the EDIS website at https://edis.ifas.ufl.edu for the currently supported version of this publication.

2. Shinsuke Agehara, assistant professor, Horticultural Sciences Department, and Syuan-You Lin, former graduate research assistant; UF/IFAS Gulf Coast Research and Education Center, Balm, FL 33598.

The Institute of Food and Agricultural Sciences (IFAS) is an Equal Opportunity Institution authorized to provide research, educational information and other services

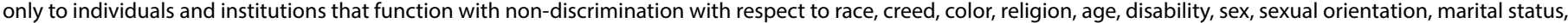

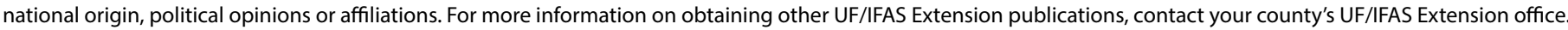
U.S. Department of Agriculture, UF/IFAS Extension Service, University of Florida, IFAS, Florida A \& M University Cooperative Extension Program, and Boards of County Commissioners Cooperating. Nick T. Place, dean for UF/IFAS Extension. 


\section{Chilling Requirements}

It is reported that current major floricane-fruiting cultivars require 300 to 900 chilling hours below $45^{\circ} \mathrm{F}$ (Carter et al. 2006; Drake and Clark 2000), whereas primocane-fruiting cultivars require about 300 chilling hours (Agehara et al. 2019). When plants do not receive adequate chilling hours, budbreak becomes poor and erratic. In central Florida, chilling hours average only about 250 hours. For more information on chilling hours in your area, visit Agroclimate (http://agroclimate.org/tools/Chill-Hours-Calculator/) and select a weather station near your farm.

\section{Chemical Budbreak Induction}

\section{Chemical Defoliation}

Chemical defoliation can be used as a budbreak induction strategy for temperate crops grown in subtropical regions (Díaz et al. 1987). At high concentrations, spray application of some fertilizers, such as urea and zinc sulfate, is highly effective in defoliating fruit crops (Chapman et al. 1979; Dhillon et al. 2018; Ferguson et al. 2007; Singh et al. 2002). For example, zinc sulfate is used to defoliate peach trees in Florida (Olmstead 2015). One of the important functions of chemical defoliation is to allow buds to be receptive to winter chilling, which in turn helps fulfill chilling requirements and reduce the depth of dormancy (Lloyd and Firth 1990; Olmstead 2015). It is also reported that some defoliants can induce budbreak independently of chill accumulation (Lin and Agehara 2021b).

\section{Research Data}

Figure 1 summarizes the data of defoliant research trials conducted in west central Florida during the 2018-2019 and 2019-2020 growing seasons (Lin and Agehara 2020b; Lin and Agehara 2021a). We tested four defoliants, including urea, lime sulfur (mainly a mixture of calcium polysulfides and thiosulfate), zinc sulfate, and potassium thiosulfate, using 'Natchez', a low-chill (300 hours) floricane-fruiting cultivar. Lime sulfur was effective in promoting budbreak, but it required an application rate that is greaterthan the maximum allowable label rate. Potassium thiosulfate caused phytotoxicity symptoms, such as cane dieback and increased mortality of flowering laterals. Therefore, the results of these two treatments are not included in this article.

In the untreated plants, the final percentage of budbreak recorded in late March ranged from 26.6\% to 31.6\% (Lin and Agehara 2020b; Lin and Agehara 2021a). Urea and zinc sulfate treatments increased budbreak up to $63.2 \%$ and $53.8 \%$, respectively (data not shown), and increased yield by up to $87 \%$ and $34 \%$, respectively, compared with the untreated control (Figure 1). Figure 2 shows the improvement in fruit earliness and fruit set by urea spray application made in late February.

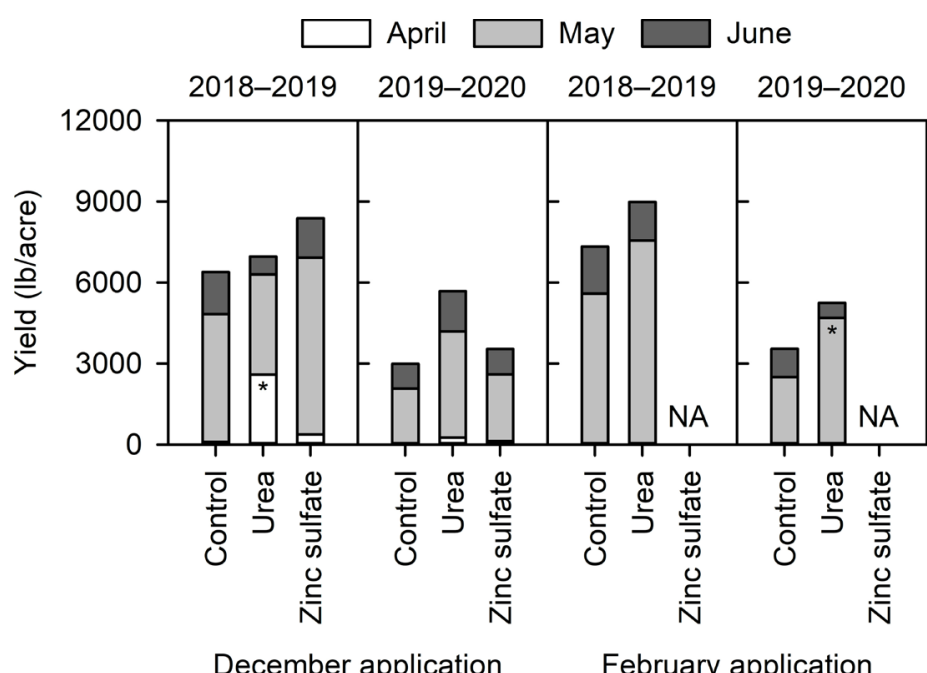

Figure 1. Yield of 'Natchez' blackberry grown in west central Florida as affected by defoliants applied in December or February in the 2018-2019 and 2019-2020 seasons. Defoliants were applied at $167 \mathrm{lb} /$ acre with a spray volume of 200 gallon/acre on 27 Dec. 2018, 19 Feb. 2019, 25 Dec. 2019, and 19 Feb. 2020. Asterisks indicate significant differences from the control (untreated plants) (Tukey-Kramer test, $\mathrm{P}$ $\leq 0.05)$. NA = data not available.

Credits: Lin and Agehara (2021a) and Lin and Agehara (2021b).

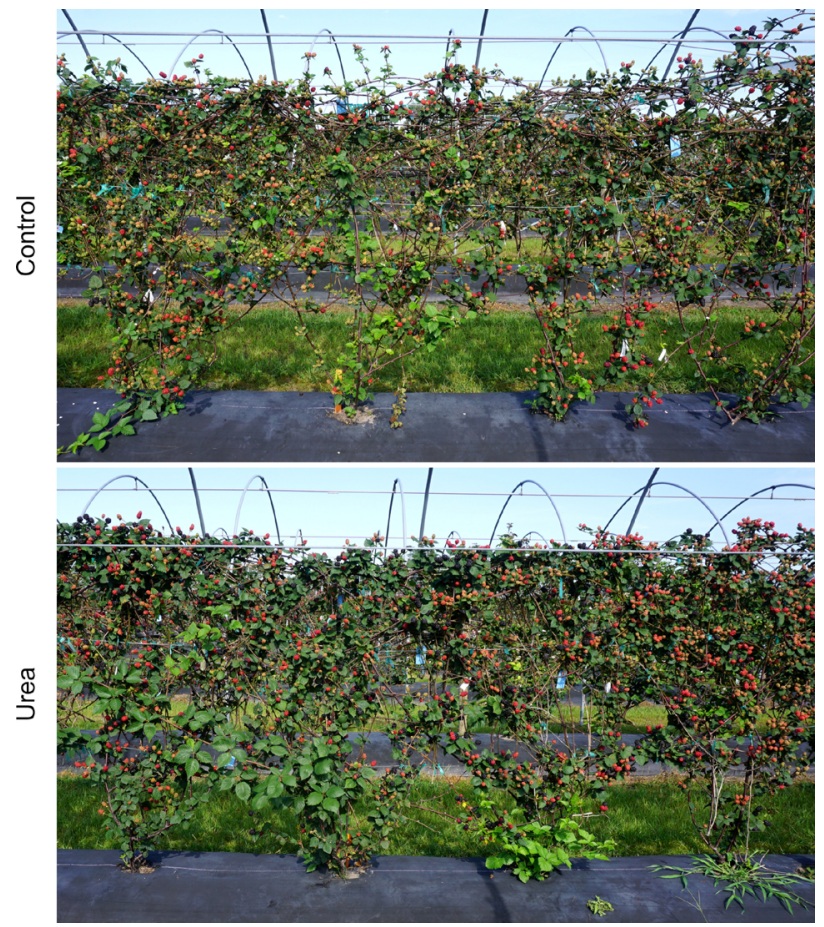

Figure 2. Improved fruit earliness and fruit set of 'Natchez' blackberry by spray application of urea. Urea was applied at $167 \mathrm{lb} / \mathrm{acre}$ with a spray volume of 200 gallon/acre on $19 \mathrm{Feb}$. 2019. The photographs were taken on 7 May 2019 during the early season harvest. Credits: Syuan-You Lin, UF/IFAS 


\section{Cultivars}

- In addition to 'Natchez', other floricane-fruiting cultivars, including 'Navaho' and 'Ouachita', have shown positive responses to the defoliants listed in this article.

- We are currently testing defoliant treatments for primocane-fruiting cultivars and a new floricane-fruiting cultivar 'Caddo'. Data are currently not available.

\section{Timing}

- To avoid the risk of freeze damage on developing flowers, we recommend making a defoliant application in midFebruary or immediately before the occurrence of natural budbreak.

- If the risk of freeze damage is minimal and improved fruit earliness is critical, application can be made earlier. In the 2018-2019 season, urea application in late December advanced the first harvest by 1 month and increased yield in April from 104 to $2593 \mathrm{lb} / \mathrm{acre}$, compared with the control.

\section{Application Rates}

- Defoliants (urea or zinc sulfate): $167 \mathrm{lb} / \mathrm{acre}$

- Nonionic surfactant (e.g., Agri-Dex): 0.5\% v/v

- Spray volume: 200 gallon/acre

\section{Costs}

- Urea + surfactant: $\$ 53 /$ acre $+\$ 14 /$ acre $=\$ 67 /$ acre

- Zinc sulfate + surfactant: $\$ 52 /$ acre $+\$ 14 /$ acre $=\$ 66 /$ acre

- The application costs are based on the prices at a local major supplier of agricultural chemicals and the application method described in this article.

\section{Recommendations and Precautions}

Our research data show that urea and zinc sulfate are effective in improving budbreak, fruit earliness, and yield of floricane-fruiting blackberry cultivars under subtropical climate conditions. Of the two defoliants, urea appears to be the ideal chemical option because of its consistent efficacy and low application cost. Urea is highly soluble in water and has a favorable safety profile. We recommend applying urea at $167 \mathrm{lb} /$ acre with a spray volume of 200 gallon/acre in mid-February or immediately before natural budbreak. This application timing can maximize the budbreak induction effect, while avoiding the risk of freeze damage on developing flowers.

\section{Literature Cited}

Agehara, S., S.-Y Lin, and Z. Deng. 2019. "Choosing the Right Blackberry Cultivar in Subtropical Florida." EDIS 2020 (1). https://doi.org/10.32473/edis-hs1354-2020

Carter, P. M., J. R. Clark, C. D. Particka, and D. Y. Crowne. 2006. "Chilling Response of Arkansas Blackberry Cultivars." J. Amer. Pomol. Soc. 60:187-197.

Chapman, K. R., J. Saranah, and B. Paxton. 1979. "Induction of Early Cropping of Guava Seedlings in a Closely Planted Orchard Using Urea as a Defoliant." Austral. J. Expt. Agr. 19 (98): 382-384. https://doi.org/10.1071/ea9790382

Dhillon, J. S., R. S. Boora, D. S. Gill, and N. K. Arora. 2018. "Effect of Different Chemicals and Hand Thinning on Crop Regulation in Guava (Psidium guajava L.) cv. Shweta." Agr. Res. J. 55 (2): 365-369. https://doi. org/10.5958/2395-146X.2018.00067.4

Díaz, D. H., A. Alvarez, and J. Sandoval. 1987. "Cultural and Chemical Practices to Induce Uniform Bud Break of Peach and Apple under Warm Climates in Mexico." Acta Hort. 199:129-136. https://doi.org/10.17660/ actahortic.1987.199.31

Drake, C. A., and J. R. Clark. 2000. "Determination of the Chilling Requirement of Arkansas Thornless Blackberry Cultivars." The Student Journal of Dale Bumpers College of Agricultural, Food Life Sci. 1:14-19.

Ferguson, J., J. Chaparro, J. Williamson, R. Rouse, and R. Mizell. 2007. "Florida Subtropical Peaches: Production Practices.” EDIS 2007 (20). https://journals.flvc.org/edis/ article/view/117046

Lin, S.-Y., and S. Agehara. 2020a. "Exogenous Gibberellic Acid Advances Reproductive Phenology and Increases Early-Season Yield in Subtropical Blackberry Production." Agronomy 10 (9): 1317. https://doi.org/10.3390/ agronomy10091317

Lin, S.-Y., and S. Agehara. 2020b. "Exogenous Gibberellic Acid and Cytokinin Effects on Budbreak, Flowering, and Yield of Blackberry Grown under Subtropical Climatic Conditions." HortScience 55 (12): 1938-1945. https://doi. org/10.21273/hortsci15381-20 
Lin, S.-Y., and S. Agehara. 2021a. "Foliar Application of Defoliants after Winter Chill Accumulation Changes Phytohormone Dynamics and Improves Budbreak in Blackberry under Subtropical Climatic Conditions." Plant Growth Regulat. 94:171-181. https://doi.org/10.1007/ s10725-021-00703-x

Lin, S.-Y., and S. Agehara. 2021b. "Foliar Application of Defoliants before Winter Chill Accumulation Advances Budbreak and Improves Fruit Earliness of Blackberry under Subtropical Climatic Conditions." HortScience 56 (2):

210-216. https://doi.org/10.21273/hortsci15533-20

Olmstead, M. 2015. “Defoliating Peaches.” Accessed Feb. 27, 2021. https://crec.ifas.ufl.edu/extension/trade_journals/2015/2015_September_peaches.pdf

Singh, G., A. K. Singh, S. Rajan, and S. R. Bhriguvanshi. 2002. "Strategy for Crop Regulation in Guava (Psidium guajava L.) through Foliar Urea Sprays and Its Effect on Different N-forms in Leaves." J. Appl. Hort. 4 (2): 93-98. https://doi.org/10.37855/jah.2002.v04i02.26

US Department of Agriculture. 2017. “Quick Stats.”

Accessed Feb. 27, 2021. https://quickstats.nass.usda.gov/ results/08D195DC-7B67-32E7-9167-4314A69E6E69 